\title{
Tolerances and requirements of embryos and larvae of bivalve molluscs
}

\author{
A. Calabrese and H. C. Davis \\ Bureau of Commercial Fisheries, Biological Laboratory; \\ Milford, Connecticut, USA
}

KURZFASSUNG: Toleranzen und Umweltansprïche der Embryonen und Larven von Muscheln. Es werden Verfahren diskutiert, die es gestatten, Embryonen und Larven von Muscheln das ganze Jahr hindurch zu gewinnen. Diese basieren auf der Auslösung der Gonadenentwicklung geschlechtsreifer Muscheln im Winter und Frühjahr und der ausschließenden Verzögerung der Keimzellenentleerung bis zum Herbst und Frühwinter. Die Aufzucht von Larven, wie sie im Routineverfahren möglich ist, wird beschrieben. Nahrungs-, Temperatur-, Salinitäts- und pH-Ansprüche sowie die Wirkung verschiedener Faktorenkombinationen auf Uberlebensrate und Wachstum der Larven einiger Arten werden dargestellt. Ferner wird über Toxizitätsstudien an Larven und über Fortschritte hinsichtlich des Studiums der Genetik der Bivalvia berichtet.

\section{INTRODUCTION}

We review here some of the techniques used in rearing bivalve molluscs at the Bureau of Commercial Fisheries Biological Laboratory, Milford, Connecticut, U.S.A., and some of our findings on food requirements of larvae and the tolerance of embryos and larvae to temperature, salinity, $\mathrm{pH}$, and various toxic substances.

It is difficult to discuss techniques for rearing bivalve molluscs because techniques should always be adapted to the purpose of the investigation. If only a few individuals are needed to determine the morphology at successive stages of the life cycle, it may be possible to obtain enough larvae for the study by stripping eggs and sperm from mature animals. If studies on the tolerance of the developing embryonic and larval stages to environmental factors, such as temperature, salinity, and $\mathrm{pH}$, are to be carried out, however, far more eggs and larvae are needed to yield significant results.

We prefer to induce the parent stock to spawn rather than to strip the eggs and sperm because, in addition to obtaining more eggs, we eliminate the broken tissue usually obtained in stripping and most of the immature eggs. Almost all of the spawned eggs develop into straight-hinge larvae if reared under the optimum conditions for development of the embryos. This high development rate permits us to determine the effects of different factors, such as temperature, on the percentage of embryos that will develop normally. Moreover, we usually induce several males and 
females to spawn and pool the eggs so that the larvae will be more representative of the population from which the parents were derived. To induce spawning in the American oyster Crassostrea virginica and the hard clam Mercenaria mercenaria we place them in Pyrex baking dishes filled with sea water and raise the temperature in the water bath surrounding the spawning dishes. If a temperature of about $28^{\circ} \mathrm{C}$ does not induce the animals to spawn, we add stripped sperm from a sacrificed male to the spawning dishes. The combination of increased temperature and added sperm usually induces spawning. The eggs from all females are collected into a large jar by pouring the contents of each dish through a stainless steel screen of fine enough mesh to remove feces and other debris that accumulate in the spawning dishes, while permitting the fertilized eggs to pass through. The contents of the jar are thoroughly agitated to attain a uniform suspension of eggs, and a $1-\mathrm{ml}$ volumetric sample is withdrawn to determine the number of eggs present. We can then calculate the volume necessary to give the desired number of eggs per culture (usually 30,000 eggs/l). Knowing the number of eggs put into each container, we can later determine what percentage develops to the straight-hinge larval stage.

It is very simple to induce spawning of oysters and clams at Milford because we are able to maintain these animals in spawning condition almost throughout the year (Loosanoff \& Davis 1963). Loosanoff (1945), while attempting to kill boring sponge in the shells of oysters by keeping the oysters at elevated temperatures, found that oysters could be conditioned to spawn in mid-winter by holding them at temperatures of $20^{\circ}$ to $25^{\circ} \mathrm{C}$. Although oysters normally go through the winter with only undifferentiated germ cells in the gonad, they require only a few days at $30^{\circ} \mathrm{C}$ to develop active sperm and fertilizable eggs, somewhat longer at $25^{\circ} \mathrm{C}$, and 2 to 3 weeks at $20^{\circ}$ to $21^{\circ} \mathrm{C}$. We prefer to condition oysters at about $21^{\circ} \mathrm{C}$, however, because at higher temperatures spawning frequently occurs in the conditioning trays. Although such spawning is much less likely at $21^{\circ} \mathrm{C}$, we hold oysters with ripe gonads at $15^{\circ}$ to $18^{\circ} \mathrm{C}$ to prevent them from spawning until needed. We can usually induce ripe oysters to spawn within 15 to 30 minutes, although it sometimes takes longer.

To have spawners available from mid-August until December (when we can bring them to spawning condition by keeping them at elevated temperatures) we place clams and oysters in a cold, running sea water apparatus at $15^{\circ} \mathrm{C}$ in late May or early June. Oysters develop gonads very slowly at this temperature and remain in spawning condition until late fall, when they begin to resorb the gonad material. Clams do not resorb the unspawned gametes and remain in spawning condition throughout the ensuing winter.

In developing methods for rearing bivalve molluscs, as with other marine invertebrates, the kind and quantity of food required must be considered, as well as the range of temperature, salinity, and $\mathrm{pH}$ tolerated. In addition, one must be aware of possible toxicants and diseases.

\section{FOOD STUDIES}

The food provided for bivalve larvae must be of the proper size to be ingested, digestible, and contain the necessary carbohydrates, fats, proteins, and vitamins. 
These requirements essentially limit us to the use of unicellular algae and for the most part to those less than $10 \mu$ in diameter. Although some bivalve larvae can digest and assimilate algae that have cell walls, such as Chlorella sp. and Dunaliella sp., other larvae require the naked flagellates, such as Monochrysis lutberi and Isochrysis galbana. All species of bivalve larvae that we have reared appear to utilize the naked flagellates more readily than forms with cell walls.

We have reared larvae to metamorphosis on a number of species of algae, indicating that any one of these provided all the essential food requirements. Nevertheless, larvae of the hard clam and American oyster grow more rapidly on a mixture of several species of algae rather than on any single species; a mixture of chrysomonads with some of the green algae appears to provide a more balanced diet than any species of algae separately.

We believe the food value, to bivalve larvae, of any species of algae is determined largely by whether the algae have cell walls and by the type of metabolites the algae produce. Isochrysis galbana, Monochrysis lutberi, and some other chrysomonads apparently produce few or no toxic metabolites, whereas Prymnesium parvum, still another chrysomonad, produces highly toxic metabolites. These toxins may be primarily internal or primarily external. If they are primarily internal, the larvae feed and look normal for a day or so, then die. If they are primarily external, the larvae die without feeding. Other algae, such as Chlorella sp. (580)*, produce metabolites that are somewhat less toxic. If they are fed in the proper concentration, larvae that can utilize this species survive and grow; higher concentrations cause slow growth and eventually death. It can be shown that some of the toxic metabolites of Chlorella sp. (580) are external; if a Millipore filtrate of this alga is added to a larval culture in a quantity equivalent to the heavier rate of feeding, it will also kill the larvae.

Our experience at Milford has shown that if algal cultures become bacterized, even good food species, such as Monochrysis lutheri and Isochrysis galbana, may be very toxic, particularly to oyster larvae, even though the algal cultures appear healthy and continue to grow well. This toxicity is manifested by a drastically reduced rate of growth of larvae and, if the toxin is present in sufficient concentration, by complete cessation of growth or death of the larvae. It should also be pointed out, however, that other bacterized cultures may continue to provide good food for larvae for a year or more. Thus, certain species of bacteria apparently produce highly toxic metabolites and others do not.

\section{TEMPERATURE AND SALINITY STUDIES}

At Milford we have studied the combined effects of temperature and salinity on the percentage of embryos that develop into normal larvae and on the survival and growth of the larvae in the hard clam and American oyster (DAvis \& CALABrESE 1964) and the coot clam, Mulinia lateralis (CALABreSE 1969). In studying the effects of these factors on growth, it was necessary to know whether the food provided

\footnotetext{
* Cblorella sp. (Indiana University Collection \# 580).
} 
was available to the larvae under the conditions of the experiment. While investigating the reasons for erratic results in experiments in which Monocbrysis lutberi and Isochrysis galbana were fed to bivalve larvae at temperatures of $27.5^{\circ} \mathrm{C}$ and above,

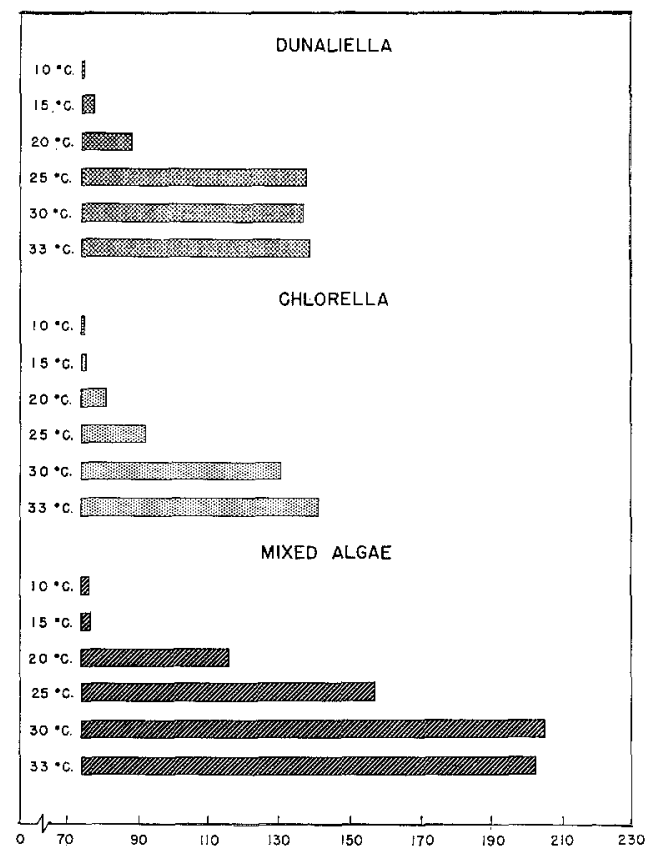

Fig. 1: Growth of Crassostrea virginica larvae receiving different foods and reared at different temperatures. (After Davis \& CALABRESE 1964)

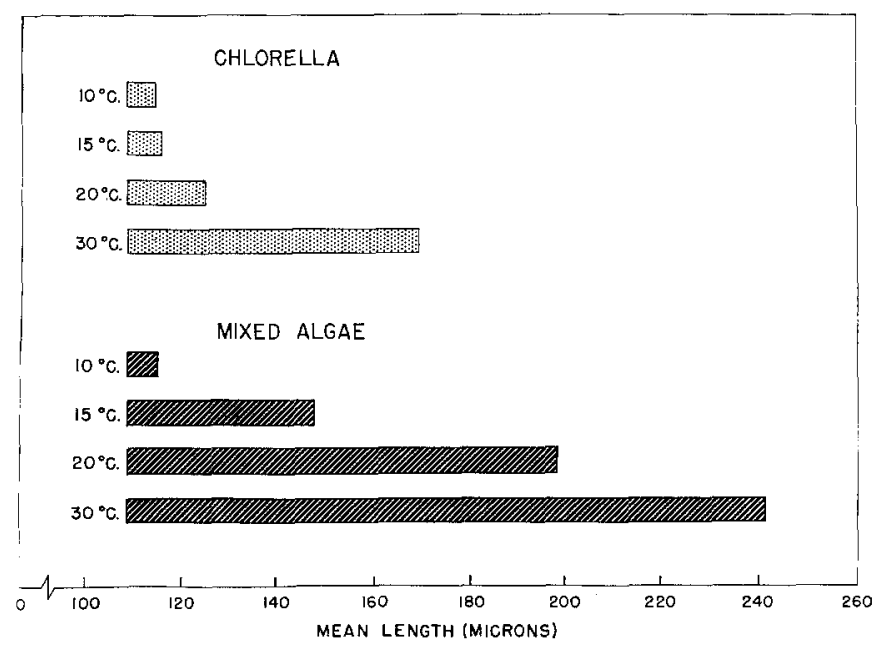

Fig. 2: Growth of Mercenaria mercenaria larvae receiving different foods and reared at different temperatures. (After Davis \& CALABRESE 1964) 
we learned that the algae died and the cells disintegrated at these temperatures. We, therefore, studied the effect of several foods on growth at different temperatures.

In one experiment we fed Dunaliella eucblora, Chlorella sp. (580), or a mixture of Isochrysis galbana, Monochrysis lutheri, Dicrateria sp. (B II), and Chlorella sp. (580) to oyster larvae. Growth of larvae was not appreciable at $10^{\circ}$ and $15^{\circ} \mathrm{C}$, although some food was ingested (Fig. 1). At $20^{\circ} \mathrm{C}$ larvae grew much better on the mixture of algae than on Dunaliella euchlora or Chlorella sp. (580). Since the growth of larvae receiving Chlorella sp. (580) increased progressively through $33^{\circ} \mathrm{C}$, whereas the growth of larvae receiving the mixture decreased from $30^{\circ}$ to $33^{\circ} \mathrm{C}$, we assumed that $M$. lutheri and $I$. galbana were destroyed and no longer available.

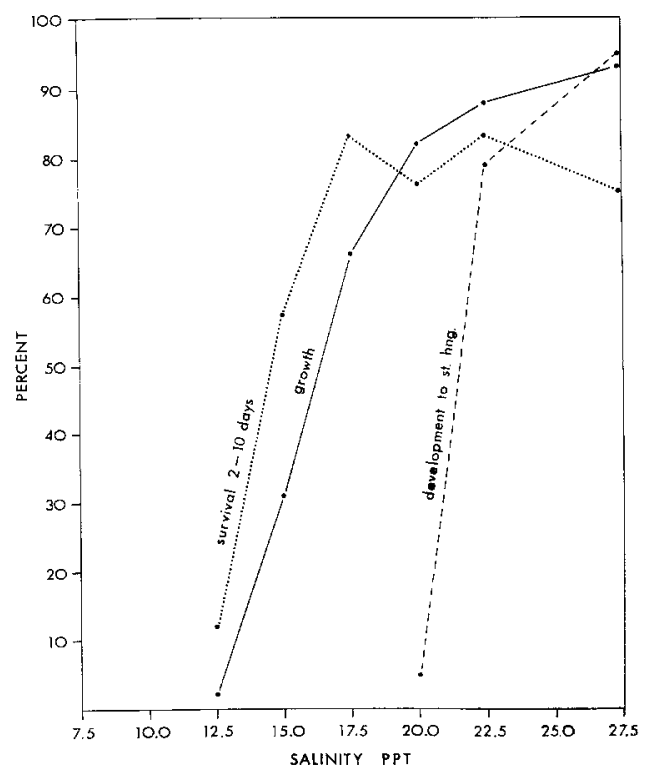

Fig. 3: Effect of salinity (at $25^{\circ} \mathrm{C}$ ) on embryonic development of Mercenaria mercenaria and on survival and growth of the larvae. (After Davis 1969)

An experiment with clam larvae showed even more dramatically that larvae at $15^{\circ} \mathrm{C}$ could ingest but not digest and assimilate Chlorella sp. (580), although they could utilize the naked flagellates (Fig. 2).

We used a mixture of algae, therefore, in our temperature-salinity experiments to give the best available coverage of the food requirements of larvae throughout the range of temperatures tested.

The hard clam is much less tolerant of low salinities than are other species of bivalves (Davis \& Calabrese 1964). A graph (Fig. 3) of the percentage of clam embryos developing to the straight-hinge stage, larval survival from 2 to 10 days, and increase in mean length of larvae at $25^{\circ} \mathrm{C}$ shows that rearing of larvae and recruitment of larvae into a population is limited to areas having salinities above 22 p.p.t; at lower salinities most embryos fail to develop to the straight-hinge stage. 
The larvae, however, can survive and grow reasonably well at salinities of 17.5 or even 15 p.p.t.

Larvae of American oysters from Long Island Sound can be reared in areas where the salinity remains above 17.5 p.p.t. (Fig. 4). Oyster larvae, like hard clam larvae, once they reach the straight-hinge stage, can survive and grow at lower salinities. When embryos of oysters were allowed to develop to the straight-hinge stage at 12.5 to 15 p.p.t. we were able to rear the larvae to metamorphosis at salinities as low as 10 or even 7.5 p.p.t. Nevertheless, growth of the larvae at 7.5 and 10 p.p.t. was appreciably slower than that of sibling larvae reared at higher salinities.

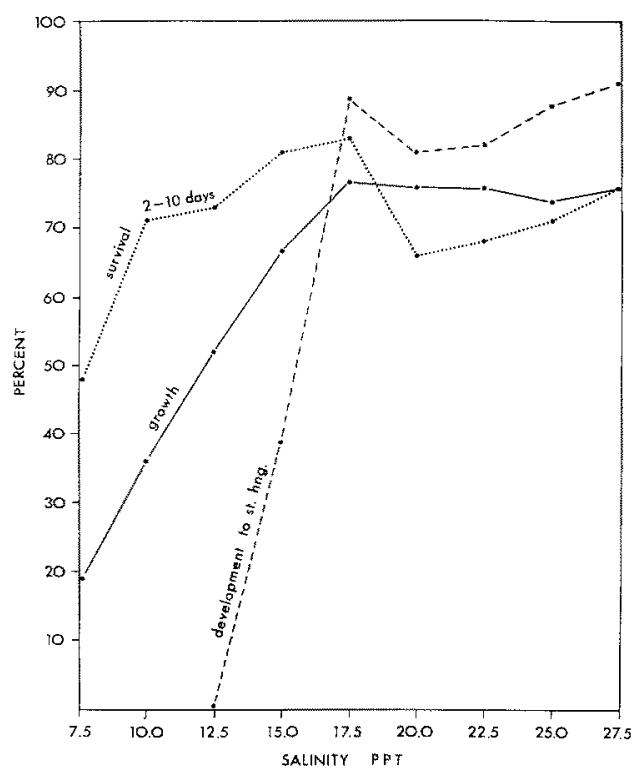

Fig. 4: Effect of salinity (at $32.5^{\circ} \mathrm{C}$ ) on embryonic development of Crassostrea virginica and on survival and growth of the larvae. (After Davis 1969)

Proper temperature is very important in rearing bivalve larvae. At a salinity of $27.5 \pm 1.0$ p.p.t. American oyster larvae grow best at $32.5^{\circ} \mathrm{C}$ (Fig. 5). A good percentage of embryos can develop to the straight-hinge stage at temperatures so low that growth of the larvae is extremely slow. The temperature requirement for rearing American oyster larvae is, therefore, determined primarily by the effect of temperature on growth.

Growth of hard clam larvae, however, is much less affected by temperature (Fig. 6); that is, growth of these larvae is satisfactory over a considerably wider range of temperatures.

Davis \& CALABRESE (1969) determined that the average rate of growth of larvae of the European oyster, Ostrea edulis, increased progressively from $10^{\circ}$ to $25^{\circ}$ or $27.5^{\circ} \mathrm{C}$ and then decreased at $30^{\circ}$ and $32.5^{\circ} \mathrm{C}$ (Fig. 7). Although some growth did occur at $10^{\circ}$ and $12.5^{\circ} \mathrm{C}$ and some larvae reached setting size at $12.5^{\circ}$ and $15^{\circ} \mathrm{C}$, no spat were obtained below $17.5^{\circ} \mathrm{C}$. Growth was satisfactory only within the range 
from $17.5^{\circ}$ to $30^{\circ} \mathrm{C}$. Survival was much more erratic than growth. Except for cultures kept at $10^{\circ}, 30^{\circ}$, and $32.5^{\circ} \mathrm{C}$, the average percentage survival at each temperature was within the acceptable range (70 per cent or more of maximum).

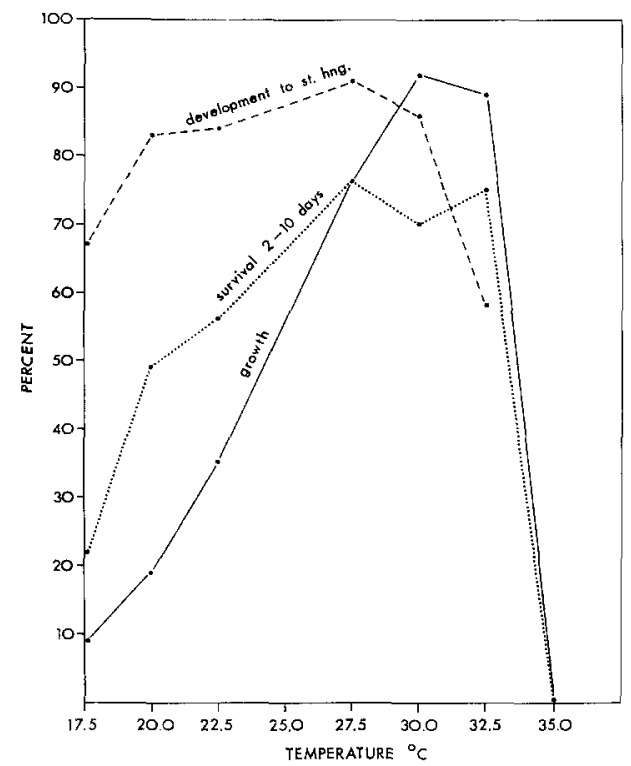

Fig. 5: Effect of temperature (at 27.5 p.p.t. salinity) on embryonic development of Crassostrea virginica and on survival and growth of the larvae. (After DAvis 1969)

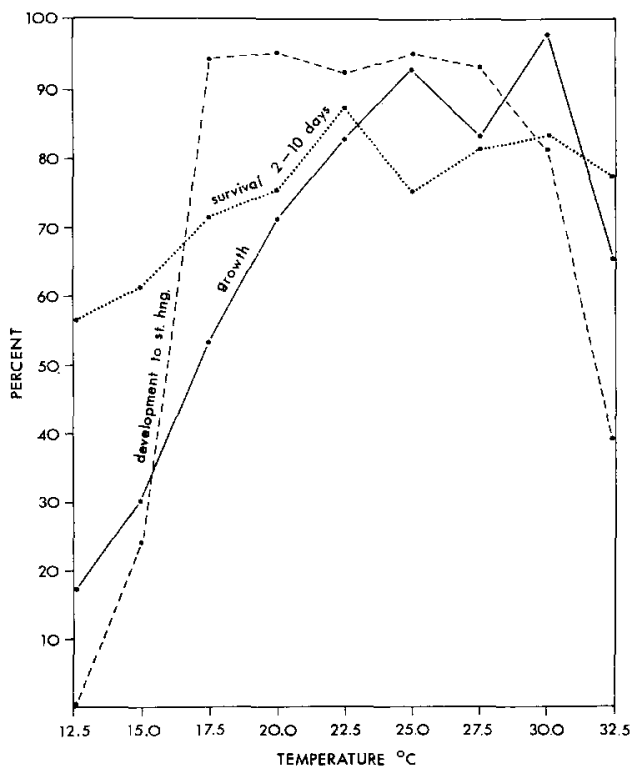

Fig. 6: Effect of temperature (at 27.5 p.p.t. salinity) on embryonic development of Mercenaria mercenaria and on survival and growth of the larvae. (After DAvIs 1969) 
CALABRESE (1969), who studied the combined effect of salinity and temperature on larvae of the coot clam, Mulinia lateralis, found that although a significant percentage of the larvae survived a wide range of salinities from 10 to 35 p.p.t. and temperatures from $7.5^{\circ}$ to $27.5^{\circ} \mathrm{C}$, they were able to grow best only within the salinity range from 20 to 35 p.p.t. (highest tested) and the temperature range from $22.5^{\circ}$ to $27.5^{\circ} \mathrm{C}$.

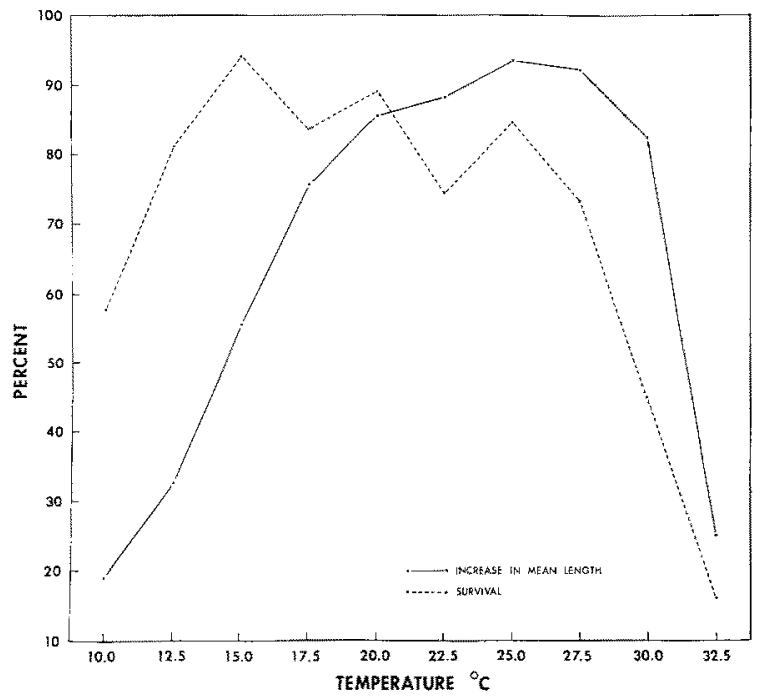

Fig. 7: Survival and growth of larvae of Ostred edulis at different temperatures. (After Davis \& Calabrese 1969)

It should be emphasized that the data given are for survival and growth of larvae. Larvae can and do set at lower temperatures and salinities than those at which they show satisfactory growth. At the same time it should be emphasized that the larvae can live for a considerable time at temperatures and salinities at which they will not grow. Consequently, living larvae may be found in nature as "accidental inhabitants" in waters where growth is prevented by the temperature or salinity or both.

\section{pH STUDIES}

We also studied the effect of $\mathrm{pH}$ on the embryonic development and survival and growth of larvae of the hard clam and American oyster (CALABRESE $\&$ DAvis 1966) and the coot clam (CALABrese 1969). The larvae of all three species tolerate a considerably wider range of $\mathrm{pH}$ than the embryos. We concluded, however, that for successful recruitment of hard clams and American oysters the $\mathrm{pH}$ of tidal estuarine waters that form their principal habitat must not fall below 7.00 for clams or 6.75 for oysters for any appreciable time. Moreover, neither species could reproduce successfully in waters where the $\mathrm{pH}$ remained appreciably above 9.00 . The 
coot clam tolerates a much smaller range and would not be able to reproduce successfully below $\mathrm{pH} 7.25$ or above $\mathrm{pH} 8.25$.

\section{TOXICANT STUDIES}

To rear bivalve larvae successfully, toxicants and diseases must be avoided. Bivalve larvae are surprisingly tough - as we have indicated by their temperature, salinity, and $\mathrm{pH}$ tolerances - and can survive rather severe physical disturbances, as when we stir them vigorously before taking quantitative samples. They can be killed, nevertheless, by surprisingly low concentrations of certain toxicants and, at least under laboratory and hatchery conditions, are subject to disease.

At Milford we studied the tolerance of bivalve embryos and larvae to a wide variety of pollutants and toxicants, including detergents, oils, solvents, insecticides, herbicides, bactericides, disinfectants, and turbidity-producing substances (Davis 1960, 1961, Hidu 1965, Calabrese \& Davis 1967, Davis \& Hidu 1969a, b). Only a few general features of these experiments are discussed here.

First, some substances improve the rate of growth of clam or oyster larvae at certain concentrations (usually low). Larvae grew more rapidly in cultures treated with Guthion (insecticide), Endothal (herbicide), Phenol (bactericide), Combistrep (antibiotic), Sulmet (sulfa compound), and kaolin, than in untreated control cultures. The degree to which appropriate concentrations of these various substances increased the rate of growth was comparable. In fact, the effects of Sulmet and kaolin were so nearly identical in several experiments that we suspected the mode of action to be similar. Kaolin probably was adsorbing some of the toxins present in the sea water or food cultures and Sulmet was chelating the same toxins. Since most of the substances that increased growth were compounds of high molecular weight, it seems probable that each was adsorbing or chelating toxins.

A second finding in our experiments is that, in general, the first indication of toxicity is a marked reduction in the growth of larvae; that is, if the gradation of concentrations of a toxicant being tested is sufficiently close, we normally get a drastic reduction in growth of the larvae at concentrations lower than those required to kill the larvae. Rate of growth is, in fact, our criterion for distinguishing between a mortality due to disease and one due to toxicity. If the larvae are growing normally and mortality is high, we suspect that a disease organism is the causative agent. If the larvae are not growing and mortality is high, we suspect something toxic has entered the culture system.

We should list some of the things we have found to be highly toxic to bivalve larvae. Brass or other copper-containing metals should be eliminated from culture systems as should some of the alloys of stainless steel. Although we do use stainless steel screens, sea water cannot remain in contact with any of the stainless steels we have tested for more than a few minutes without making the sea water useless for our work. Although new lead is somewhat toxic, it is usable because it quickly develops a basic carbonate coating. Cast iron also appears to be nontoxic but not steel. Some of the plastics are also toxic and all require testing before being used 
routinely. Even the colored polyethylenes usually need to be leached out in sea water before they are usable, although we have never found evidence of toxicity in white or natural color polyethylene, polypropylene, or polycarbonate. Unplasticized poly vinyl chloride (PVC) is also apparently nontoxic.

In our new laboratory we have PVC piping for our sea water, which we thought we had tested thoroughly. Initially, the percentage of oyster embryos that developed to straight-hinge larvae was as high as that obtained from the same group of embryos in sea water from the old laboratory (which has lead piping). The peculiar thing was, however, that larvae reared to the straight-hinge stage in sea water from the old laboratory grew well in the new laboratory sea water, whereas larvae reared to straight-hinge in the new laboratory did not grow. Also, larvae reared to straight-hinge in the new laboratory would not grow in the old laboratory, whereas those reared to this stage in the old laboratory grew normally. We had not previously observed this type of toxic effect, i. e., one that did not hinder embryonic development but prevented growth of larvae, even though they were removed from the toxic environment. We do not know how common is this type of reaction to a toxin. We have found subsequently that sea water from either laboratory may, at times, show a similar toxicity. Consequently, we do not know whether the sea water system of the new laboratory was somewhat toxic initially or whether the difference was simply the result of different sources of sea water.

One of the peculiar features of this abnormality in growth of larvae was that frequently a small percentage of the larvae in these cultures grew at an approximately normal rate. Our Geneticist, Dr. A. LoNGwell, has discovered that our oysters apparently carry a very heavy load of deleterious genes, as indicated by abnormalities in full- and half-sib crosses. We have a wide range of genetic combinations in our experiments because we normally combine eggs from several females, and each female has been exposed to sperm from several males. We believe that a few of the resulting gene combinations, even in the presence of slightly toxic sea water, yield larvae capable of normal growth, whereas most combinations of deleterious genes, in the presence of these toxins, yield larvae incapable of further growth. In the absence of such toxins, however, only a few of the combinations yield larvae incapable of further growth and these are the few larvae that die early in normal cultures.

\section{IMPLICATION OF ENVIRONMENTAL FACTORS}

That tolerances to various environmental factors and toxicants, as well as the food requirements of bivalves, may be different at different stages of the life cycle is obvious, of course, in those forms in which the feeding mechanism or habitat of the larval stages differs markedly from that of the adult. Similar, but far more subtle differences may occur, however, in species in which the larval feeding mechanism and habitat are similar or identical to those of the adult.

The tolerances and requirements may differ even between larval stages. Early straight-hinge oyster larvae kept at $23^{\circ}$ to $25^{\circ} \mathrm{C}$, for example, do not use Chlorella 
sp. (580), but later umbone stages apparently can consume and digest this food at these temperatures. Food requirements may also differ under different environmental conditions. Hard clam larvae can use Chlorella sp. (580) and grow at temperatures of $25^{\circ}$ to $30^{\circ} \mathrm{C}$, but not at $15^{\circ} \mathrm{C}$. They can grow at $15^{\circ} \mathrm{C}$, however, if provided a diet of naked flagellates.

The ability to use Cblorella sp. (580) also presents a curious example of changing requirements in the American oyster. As stated previously, early straight-hinge oyster larvae apparently do not use Chlorella sp. (580) at temperatures of $23^{\circ}$ to $25^{\circ} \mathrm{C}$ but at $30^{\circ} \mathrm{C}$ there is evidence that they do so. Older umbone larvae, however, subsist on this alga at $23^{\circ}$ to $25^{\circ} \mathrm{C}$, as well as at the higher temperatures. Nevertheless, P. E. Chanley (unpublished data) found Chlorella sp. (580) to be a very poor food for oyster spat and FLoxD (1952), who used radioactive tracer techniques, concluded that adult oysters made virtually no use of Chlorella.

Salinity tolerance of larvae of the hard clam, coot clam, and American oyster also varies with temperature and with the stage of development of the larvae. Very few eggs of Long Island Sound oysters will develop to straight-hinge larvae at 12.5 p.p.t., yet larvae reared to the straight-hinge stage at 27.5 p.p.t. survive and grow at an approximately normal rate when reared at a salinity of 12.5 p.p.t. and $30^{\circ} \mathrm{C}$. Moreover, larvae reared to setting size at 27.5 p.p.t. can successfully complete metamorphosis in salinities as low as 9 or 10 p.p.t. If Long Island Sound oysters develop gonads and spawn at normal salinity ( $27.5 \pm 1.0$ p.p.t.), the eggs do not develop at 10 p.p.t. and we have not been able to rear straight-hinge larvae from such eggs to setting size at this salinity. We are not yet certain, however, how much these limits may be affected by the salinity at which the parent oysters develop gonads and spawn.

We tend to assume that tolerance to any given factor will increase as bivalve embryos develop to larval and adult stages, but this relation does not invariably hold true. We have occasionally encountered what seems to be the reverse situation in some of our studies, most notably with toxicants. Most toxicants will prevent normal embryonic development at lower concentrations than are required to kill larvae in 48 hours, but we have found several that will retard growth drastically and eventually kill oyster larvae at lower concentrations of the toxicant than are required to prevent normal embryonic development. We interpret this as a lower tolerance of the larvae because the effect on growth is immediate and continuous. Since it may take some time, however, for the lethal effect to show up, we believe death may be due to accumulation of the toxicants in the larvae.

\section{SUMMARY}

1. Techniques are discussed for obtaining bivalve embryos and larvae throughout the year by inducing gonad development in adults during winter and spring and retarding spawning until late fall and early winter.

2. Development of routine methods for rearing larvae is described and data are presented on the food, temperature, salinity, and $\mathrm{pH}$ requirements and on the 
effect of different combinations of these factors on survival and growth of larvae of several species of bivalves.

3. Some general conclusions are given on the effects of suspended materials, various pollutants, and toxicants on embryos and larvae.

4. Progress in the study of genetics of bivalves is reported.

\section{LITERATURE CITED}

Calabrese, A., 1969. The early life history and larval ecology of the coot clam, Mulinia lateralis (Say) (Mactridae: Pelecypoda). Ph. D. thesis, Univ. of Connecticut, Storrs.

- \& Davis, H. C., 1966. The $\mathrm{pH}$ tolerance of embryos and larvae of Mercenaria mercenaria and Crassostrea virginica. Biol. Bull. mar. biol. Lab., Woods Hole 131, 427-436.

- - 1967. Effects of "soft" detergents on embryos and larvae of the American oyster (Crassostrea virginica). Proc. natn. Shellfish. Ass. 57, 11-16.

Davis, H. C., 1960. Effects of turbidity-producing materials in sea water on eggs and larvae of the clam (Venus [Mercenaria] mercenaria). Biol. Bull. mar. biol. Lab., Woods Hole 118, $48-54$.

- 1961. Effects of some pesticides on eggs and larvae of oysters (Crassostrea virginica) and clams (Venus mercenaria). Comml Fish. Rev. 23, 8-23.

- 1969. Shellfish hatcheries - present and future. Trans. Am. Fish. Soc. 98, 743-750.

- \& Calabrese, A., 1964. Combined effects of temperature and salinity on development of eggs and growth of larvae of $M$. mercenaria and C. virginica. Fishery Bull. Fish Wildl. Serv. U.S. 63, 643-655.

- - 1969. Survival and growth of larvae of the European oyster (Ostrea edulis L.) at different temperatures. Biol. Bull. mar. biol. Lab., Woods Hole 136, 193-199.

- \& Hidu, H., 1969a. Effects of pesticides on embryonic development of clams and oysters and on survival and grow th of the larvae. Fishery Bull. Fish Wildl. Serv. U.S. 67, 393-404.

- - 1969b. Effects of turbidity-producing substances in sea water on eggs and larvae of three genera of bivalve mollusks. Veliger 11, 316-323.

FLoYD, D. J., 1952. Foods and feeding of oysters as observed with the use of radioactive carbon. Proc. natn. Shellfish. Ass. 43, 171-180.

Hrdu, H., 1965. Effects of synthetic surfactants on the larvac of clams (M. mercenaria) and oysters (C. virginica). J. Wat. Pollut. Control Fed. 37, 262-270.

Loosanoff, V. L., 1945. Precocious gonad development in oysters induced in midwinter by high temperature. Science N.Y. 102, 124-125.

- \& Davis, H. C., 1963. Rearing of bivalve mollusks. Adv. mar. Biol. 1, 1-136.

First author's address: Dr. A. Calabrese

US Bureau of Commercial Fisheries,

Biological Laboratory

Milford, Conn. 06460, USA 